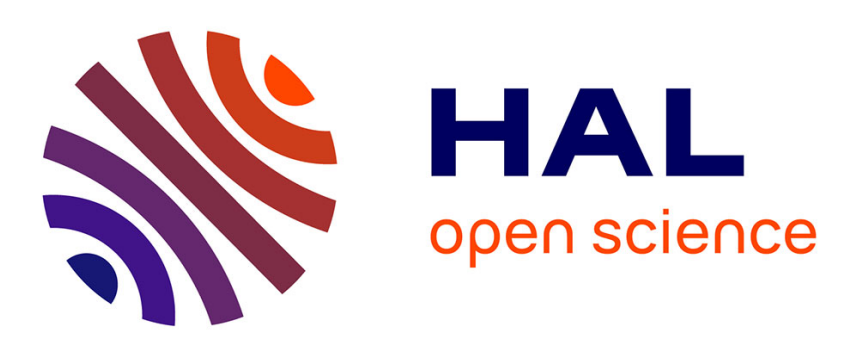

\title{
Plasma Nitriding of 90CrMoV8 Tool Steel for the Enhancement of Corrosion Resistance
}

K. Ram Mohan Rao, Corinne Nouveau, A.S. Khanna, Karanveer S. Aneja, K. Trinadh

\section{- To cite this version:}

K. Ram Mohan Rao, Corinne Nouveau, A.S. Khanna, Karanveer S. Aneja, K. Trinadh. Plasma Nitriding of $90 \mathrm{CrMoV} 8$ Tool Steel for the Enhancement of Corrosion Resistance. Materials Today: Proceedings, 2020, 24, pp.1006-1010. 10.1016/j.matpr.2020.04.413 . hal-03066650

\section{HAL Id: hal-03066650 https://hal.science/hal-03066650}

Submitted on 15 Dec 2020

HAL is a multi-disciplinary open access archive for the deposit and dissemination of scientific research documents, whether they are published or not. The documents may come from teaching and research institutions in France or abroad, or from public or private research centers.
L'archive ouverte pluridisciplinaire HAL, est destinée au dépôt et à la diffusion de documents scientifiques de niveau recherche, publiés ou non, émanant des établissements d'enseignement et de recherche français ou étrangers, des laboratoires publics ou privés. 
IConAMMA 2018

\title{
Plasma Nitriding of 90CrMoV8 Tool Steel for the Enhancement of Corrosion Resistance
}

\author{
K. Ram Mohan Rao ${ }^{\mathbf{a} *}$, Corinne Nouveau ${ }^{\mathrm{b}}$, A.S. Khanna ${ }^{\mathrm{c}}$, Karanveer S. Aneja ${ }^{\mathrm{c}}, \mathrm{K}$ Trinadh $^{\mathbf{d}}{ }^{*}$ \\ ${ }^{a}$ Department of Chemistry, GIT, Gandhi Institute of Technology \& Management (Deemed to be University), Gandhinagar, Visakhapatnam-530045, \\ Andhra Pradesh, INDIA \\ ${ }^{b}$ Laboratoire Bourguignon des Matériaux et Procédés (LaboMaP), Arts et Métiers ParisTech de Cluny, Rue Porte de Paris, F-71250, Cluny, FRANCE. \\ ${ }^{c}$ Department of Metallurgical Engineering and Materials Science, Indian Institute of Technology Bombay, Powai, Mumbai-400076, Maharashtra, INDIA

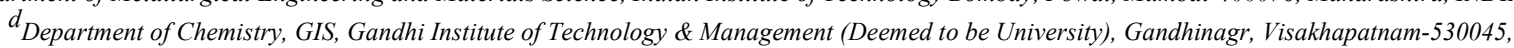

Andhra Pradesh, INDIA

\begin{abstract}
In the present studies, efforts were made to improve corrosion resistance of 90CrMoV8 tool steel by following plasma nitriding. Plasma nitriding of this steel at $500{ }^{\circ} \mathrm{C}$ for6and $8 \mathrm{~h}$ significantly improved the corrosion resistance when compared to the as-received steel. $\mathrm{X}$-ray diffraction reveals $\left.\gamma^{\prime}(\mathrm{Fe}, \mathrm{Cr}) 4 \mathrm{~N}\right)$ and $\varepsilon((\mathrm{Fe}, \mathrm{Cr}) 2-3 \mathrm{~N})$ phases formed after nitriding. Potentiodynamic polarization tests in $3.5 \% \mathrm{NaCl}$ reveal that plasma nitriding significantly improved the corrosion resistance as compared to untreated steel. The improvement in corrosion resistance may be attributed to the $\mathrm{N}$ solid solution and the presence of Fe-nitrides formed in the compound layer.
\end{abstract}

Keywords: corrosion, low alloy steel, plasma nitriding, potentiodynamic polarization

\section{Introduction}

Plasma nitriding has been accepted as one of the most industrially accepted plasma based processes for the enhancement of both mechanical and corrosion resistance properties of steels due to the presence of iron nitrides in the compound and diffusion layer [1-14]. A host of literature on nitriding elemental nitrogen adsorb on the surface of the metal part and subsequently diffuse into the bulk of the material [22-24]. However, to our knowledge plasma nitriding and corrosion resistance properties of $90 \mathrm{CrMoV} 8$ tool steel which is used in machining industries has so far not been studied in detail. The surfaces of these tools encounter high frictional forces and corrosives in the service conditions which synergistically degrades the tool life. Hence, for the wider applications of these steels in normal atmospheric conditions such studies are necessitated.

* Corresponding author. Tel.: +919701841790; fax: +91-891-2795 311.

E-mail address:rammohanrao.k@gmail.com 
Previously, plasma nitriding of 90CrMoV8 steel had shown the improvement in hardness; however the corrosion propensity in wood juice was shown to be increased [25]. Apart from this specific wood juice electrolyte there is no other literature available so far on corrosion studies of this steel in a common electrolyte found in the atmosphere. As it is known that halides accelerate corrosion in Fe based alloys and also these are commonly found atmospheric corrodents, in the present study electrochemical investigation was conducted in $\mathrm{NaCl}$ electrolyte.

\section{Experimental Details}

\subsection{Plasma nitriding process:}

Steel samples in as-received condition were cut from a sheet to a dimension of $10 \times 10 \times 3 \mathrm{~mm}^{3}$. The composition of the steel is given as below in the Table 1 .

Table 1: Composition of $90 \mathrm{CrMoV} 8$ steel

\begin{tabular}{cccccccc}
\hline Element & $\mathrm{C}$ & $\mathrm{Si}$ & $\mathrm{Mn}$ & $\mathrm{Cr}$ & $\mathrm{Mo}$ & $\mathrm{V}$ & $\mathrm{Fe}$ \\
\hline Wt. (\%) & 0.5 & 1.0 & 0.5 & 8.0 & 1.5 & 0.5 & balance \\
\hline
\end{tabular}

After metallographic polishing and ultrasonic cleaning in acetone, samples were placed in the vacuum chamber of the nitriding reactor and evacuated to $0.5 \mathrm{~Pa}$. Then nitriding was performed in a glow discharge plasma of $\mathrm{H}_{2}$ and $\mathrm{N} 2(80: 20)$ gas mixture the temperature range of $450-500{ }^{\circ} \mathrm{C}$ for $1-8 \mathrm{~h}$.

\subsection{Microstructural characterization:}

For the structural characterization the samples after nitriding were exposed to X-ray diffraction (XRD) (XRD INEL CPS 120 diffractometer - $\theta / 2 \theta$ configuration) using Co- $k \alpha$ radiation source. Cross sections of the samples were observed in scanning electron microscope (SEM- model SEM-Jeol JSM-5900) to inspect the nitrided layer. The cross sections after metallographic polishing and etching with Villela's reagent were exposed to SEM.

\subsection{Electrochemical characterization:}

To assess the corrosion resistance property, steel samples before and after plasma nitriding were subjected to detailed corrosion tests by following potentiodynamic polarization. To carry out these tests Biologic SP300 potentiostat with EC Lab software was used. The three electrode corrosion test cell constituted was consisting of the nitrided steel sample as the working electrode with $0.636 \mathrm{~cm}^{2}$ exposed to the electrolyte,

a saturated calomel electrode (SCE) as reference electrode and a platinum counter electrode. All the tests were performed in $3.5 \%$ (wt.\%) $\mathrm{NaCl}$ electrolyte with $\mathrm{pH}=5$.

\section{Results andDiscussion}

\subsection{X-ray diffraction and phase evolution}

From the previous studies on similar steel, it was found that there was no significant improvement in micro hardness for the steel samples nitrided for shorter durations within the range of 1-5 h. However, a significant improvement of hardness was shown after nitriding for 6 and $8 \mathrm{~h}$ at all the temperatures $\left(450-520^{\circ} \mathrm{C}\right)$ [25]. It can be seen from the following Fig. 1 that, nitriding at lower temperature of $450{ }^{\circ} \mathrm{C}$ improved the hardness to $\sim 1150 \mathrm{H}_{v}$ however, the case depth formed was shallow which was only $\sim 40 \mu \mathrm{m}$ thick [25].

With the view to obtain a wider case depth and hence to prolong the tool life, in the present studies, nitriding was performed at the temperature of $500^{\circ} \mathrm{C}$ by varying the exposure time for $6 \mathrm{~h}$ and $8 \mathrm{~h}$.

Fig. 2 shows the XRD patterns of as-received and nitrided steels at $500{ }^{\circ} \mathrm{C}$ for different treatment times $(6 \mathrm{~h}$ and $8 \mathrm{~h})$. In the nitrided samples, mainly the peaks of $\mathrm{Fe}$ and $\gamma^{\prime}-(\mathrm{Fe}, \mathrm{Cr}) 4 \mathrm{~N}$ and $\varepsilon-(\mathrm{Fe}, \mathrm{Cr})_{2-3} \mathrm{~N}$ were revealed. $\mathrm{Fe}$ and other nitride peaks are much broadened, which is indicative of nitrogen incorporation in the crystal lattice.

Fig. 3 represents SEM micrographs of the cross sections of the nitrided steel at $500{ }^{\circ} \mathrm{C}$ for 6 and $8 \mathrm{~h}$. It is evident that a very thin and uniform compound layer is formed on top of the surface. After this a diffusion/hard layer was formed. This thin compound layer is known to be beneficial from the corrosion resistance point of view. The bright particles on the surface are formed by agglomeration of iron nitrides particles which depend on the nitrogen concentration [20]. 


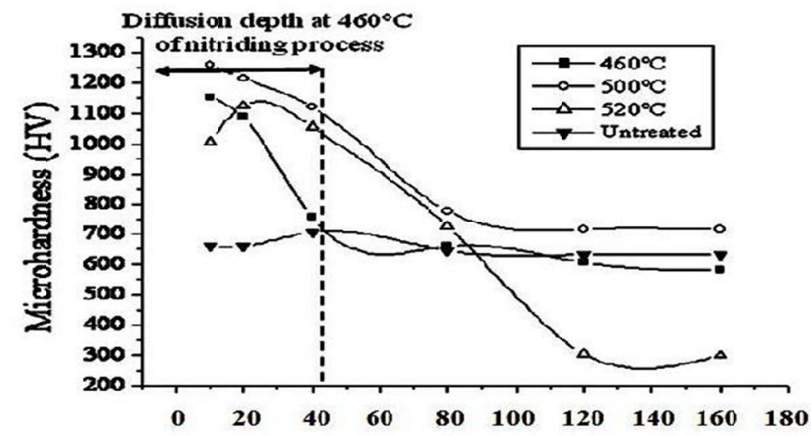

Fig. 1 Microhardness vs. depth profile of plasma nitrided steel for the duration of $10 \mathrm{~h}$ at temperatures 460,500 and $520{ }^{\circ} \mathrm{C}$ along with untreated steel [25]

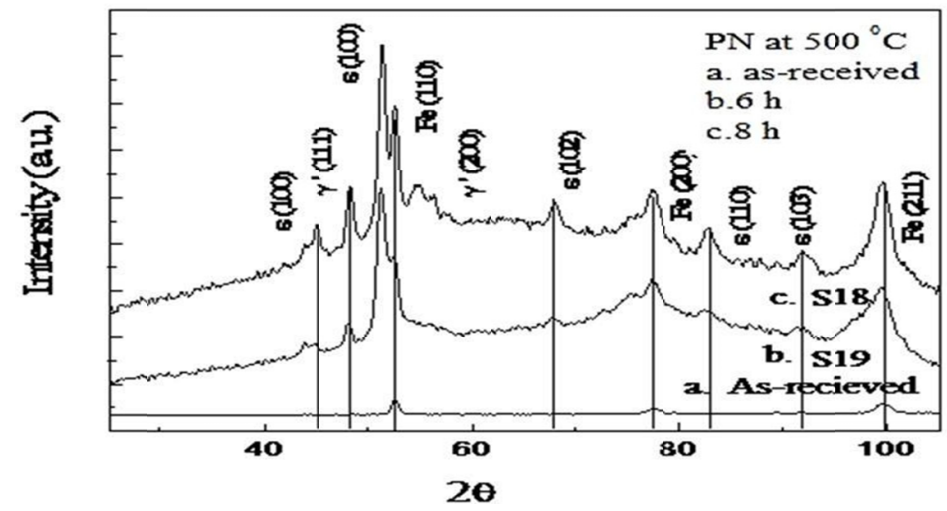

Fig.2 XRD patterns of (a) steel in as-received condition; and after plasma nitriding at $500{ }^{\circ} \mathrm{C}$ for the duration of; (b) $6 \mathrm{~h}$ (S19); and (c) $8 \mathrm{~h}$ (S18).
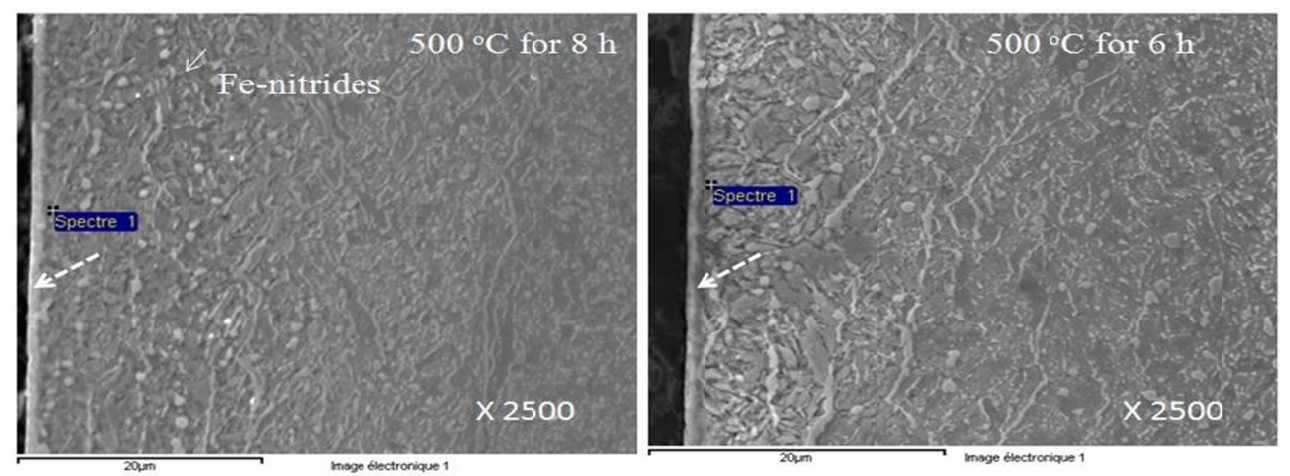

Fig. 3 SEM micrographs of $90 \mathrm{CrMoV} 8$ alloy steel after plasma nitriding at $500{ }^{\circ} \mathrm{C}$ for the durations of (a) $8 \mathrm{~h}$ and (b) $6 \mathrm{~h}$.

\subsection{Corrosion properties}

Fig.4 represents the polarization transients of steel in the as-received condition along with the steel nitrided at different condition of time at the fixed temperature of $500{ }^{\circ} \mathrm{C}$. All the corrosion tests performed at room temperature in an electrolyte containing $3.5 \%$ (by weight) $\mathrm{NaCl}$ which was freely exposed to the atmosphere. Fig. 4 shows potentiodynamic polarization plots of untreated (Bare), S18 (nitrided at $500{ }^{\circ} \mathrm{C}$ for $8 \mathrm{~h}$ ) and $\mathrm{S} 19$ (nitrided at $500{ }^{\circ} \mathrm{C}$ for $6 \mathrm{~h}$ ) samples.

Steel sample after nitriding for $6 \mathrm{~h}$ (S19) shows more positive corrosion potential than the rest of the other two nirided steel samples. Not only that a wider passivation range was shown by this steel. It was also revealed by XRD that this steel reveals $(\mathrm{Fe}, \mathrm{Cr}) 2-3 \mathrm{~N}$ phase indicating the retention of higher concentration of $\mathrm{Cr} /(\mathrm{Fe}, \mathrm{Cr})$ 2-3 $\mathrm{N}$ even after nitriding. 


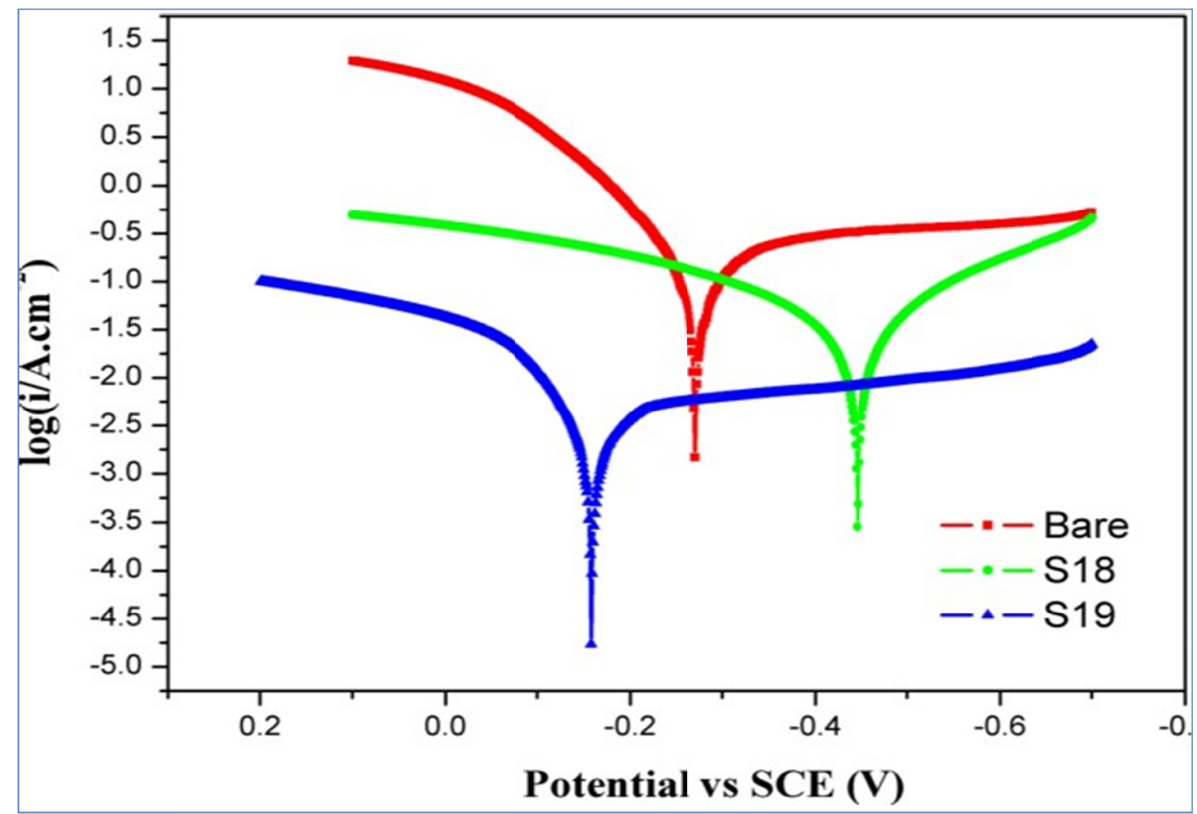

Fig. 4 Potentiodynamic Polarization of Bare, S18 and S19 samples

\section{Conclusions}

$\gamma^{\prime}-(\mathrm{Fe}, \mathrm{Cr}) 4 \mathrm{~N}$ and $\varepsilon-(\mathrm{Fe}, \mathrm{Cr}) 2-3 \mathrm{~N}$ are the nitrides formed after plasma nitriding of $90 \mathrm{CrMoV} 8$ tool steel which can improve the hardness of steel. Nitrided steels have shown significantly higher corrosion resistance than as-received steel. Presence of nitrogen in solid solution and Fe- nitrides in the nitrided layer could be responsible for the enhancement of corrosion resistance property. To meet the requirements of corrosion resistance properties of $90 \mathrm{CrMoV} 8$ tool steel, nitriding at $500^{\circ} \mathrm{C}$ treatment would a good choice.

\section{Acknowledgements}

The authors thankfully acknowledge GITAM (Deemed to be University) for kindly giving us the opportunity to carry out this research and granting the permission for the publication of the work. The technical support extended by the team members of corrosion centre of the Department of Metallurgical and Materials Engineering, IIT Bombay, Powai, India and Ecole Nationale Superier of Art et Metiers, France is gratefully acknowledged.

\section{References}

[1] A. Maniee, F. Mahboubi. and R. Soleimani, Mater. Des. 60 (2014) . 599-604

[2] E. Menthe, K.T. Rie, J. W. Schultze, Surf. Coat. Technol. 74 (1995). 412-416.

[3] M. Berg, C.V. Budtz-Jorgensen, H. Reitz, K.O. Schweitz, J. Chevallier, P. Kringhoj, Surf. Coat. Technol. 124 (2000) $25-31$.

T. Nobuteru, M. Yoshiaki, C. Akiyoshi, H. Yuji, Surf. Coat. Technol. 196 (2005). 271-274.

W. Liang., Appl. Surf. Sci. 211(2003) 308-314.

[6] T. Jun, O. Yuusuke, M. Hiroshi, K. Hideyuki, K. Shiomi, T. Imao, J. Mater. Sci. 21(1986) 2493-2496.

[7] D. Pye, 2003 Practical nitriding and ferritic nitrocarburizing ed ASM International (Materials Park: Ohio) chapter 4 pp 31- 35.

[8] M. Nikolussi, A. Leinweber, J. Mater. Res. 98 (2007) 1086-92.

[9] Z. Pokorny, V. Hruby and Z. Studeny, Metall. Mater. 54 (2016) 119-124.

[10] J.M. O'brien, D. Goodman, 1991, ASM Handbook, 4 pp. 420-424.

[11] M.K. Lei, Z.L. Zhang, Surf. Coat. Technol. 91(1997) 25-31.

[12] L. Chekour, C. Nouveau, A. Chala, M.A. Djouadi., Wear, 255 (2003) 1438.

[13] Kishora Shetty, Subodh Kumar and Raghothama Rao P., IOP Publishing, 2008, Journal of Physics: Conference Series 100062013

[14] Sh. Ahangarani, F. Mahboubi and A. Sabour, R2006 Vacuum 80 - Surface Engineering, Surface Instrumentation \& Vacuum Technology 1032

[15] X. Li C, T. Bell, Corr. Sc. 48 (2006) 2036-2049

[16] Magdalena Łepicka, Małgorzata Gradzka-Dahlke, acta mechanica et automatica, 7 (2013) 7155-159 
[17] A. Maniee, F. Mahboubi, R. Soleimani, Mater. Des. 60 (2014) 599-604

[18] A. Mashreghi, S. Soleimani, S. Saberifar, Mater. Des. 46 (2012).532-538

[19] A. Allenstein, C. Lepienski, A. Buschinelli, S. Brunatto, Appl. Surf. Sci., 277 (2013). 15-24

[20] H. Forati Rad, A. Amadeh, H. Moradi, Mater. Des.32 (2011) 2635-43

[21] D.C. Wen, Surf. Coat. Technol. 204 (2009) 511-19

[22] T. Spalvins, Ion Nitriding Conference proceedings ASM International 1986.

[23] W. Möller, S. Parascandola, T. Telbizova., R. Gunzel. and E. Richter, Surface \& Coatings Technology 136 (2001) 73

[24] ASM Handbook 5 (1996) 411

[25] Corinne Nouveau, Philippe Steyer, K. Ram Mohan Rao, Denis Lagadrillere, Surf. Coat. Technol. 205 (2011) 4514-4520. 